Agro-Science Journal of Tropical Agriculture, Food, Environment and Extension Volume 20 Number 2 (April 2021) pp. 92 - 100

ISSN 1119-7455

\title{
DOES CREDIT UTILIZATION LEAD TO INCREASING FARM OUTCOME? A MICRO-PERSPECTIVE OF TEA PRODUCTION FROM RWANDA
}

\author{
${ }^{* 1}$ Kabayiza A., ${ }^{2}$ Owuor G., ${ }^{2}$ Langat K.J., ${ }^{1}$ Mugenzi P. and ${ }^{1}$ Niyitanga F. \\ ${ }^{1}$ Department of Rural Development \& Agricultural Economics (RDAE), \\ University of Rwanda, Rwanda \\ ${ }^{2}$ Department of Agricultural Economics \& Agribusiness Management, \\ Egerton University, Kenya \\ ${ }^{*}$ Corresponding author's email: akabayiza@gmail.com; \\ ORCID: http://orcid.org/0000-0001-6224-7605
}

\begin{abstract}
Credit is a crucial factor for tea growers to pay for physical farm inputs mainly input fertilizers, research and development of high yielding tea clones and labour in order to improve the production of green tea leaf and to meet factories' demand for raw materials. However, mismanagement of accessed credits by farmers has been reported among the snags affecting the sector development. The study analyzed the determinants and impact of credit utilization on farm income among smallholder tea growers in Nyaruguru District, Rwanda. Crosssectional tea household level data were collected from 358 farmers randomly selected from tea cooperatives. The credit utilization and causal effect were estimated using the Endogenous Switching Regression model. Results showed a positive and significant relationship between credit utilization and tea farm income. Precisely, the causal effect of credit is a 7\% increase in tea income for farmers who utilised credit for tea production, while its potential effect is up to a 55\% decrease in tea income for those who divert credit for out-off tea production uses. Furthermore, training on good agricultural practices and credit management, cost of farm inputs, labour and access to group credit significantly influence utilization of credit for tea production. However, the size of credit (cash) and off-farm businesses significantly increase the diversion of credit and level of tea farm income. Tea farmers are encouraged to use tea credits for planned projects. Sensitizing farmers to procure farm input fertilizers in bulk through cooperatives should be vigorously pursued to discourage credit diversion.
\end{abstract}

Key words: tea credits, tea farming households, farm income, endogenous switching regression

\section{INTRODUCTION}

Agriculture investment is a national priority for transforming agriculture and greater financial inclusion. The yielded substantial progress in financing agriculture results from government's funding measures for access to financial services for farmers and agribusinesses through the Financial Sector Development Program (2013-2018), The National Financial Inclusion Strategy (NFIS) and the National Agriculture Policy (NAP) (GoR, 2012). Rwanda additionally so has two key market development entities-the Development Bank of Rwanda (BRD) and the Business Development Fund (BDF) both are active in the financing agriculture sector. Through the National Bank of Rwanda (NBR) there is a system of monitoring credit disbursed to the agriculture by value chains and value chain stages in all financial institutionscommercial banks, Microfinance (MFIs) and SACCOs. According to the World Bank (2018), agri-finance is a key focus area for Access to Finance, and Rwanda plays a role of a specialized donor- funded initiative and for the World Bank's lending projects. As result, the loans for agriculture increased from 57 billion in 2012 to a 90 billion in 2016 (World Bank, 2018) with agri-processing and tea production as the leading investment over this period.

Tea production was among the country priorities for reforms implemented in the agriculture transformation since 2013 because of its economic role for the country (World Bank, 2013). Tea production plays an important role in the establishment of tea factories, job creation for rural communities by increasing farmers' daily income and finally, its exports' share remains significant in the foreign exchange balance for countries like Rwanda (FAO, 2020). Furthermore, the tea sector in Rwanda offers additional advantages. In particular, tea cultivation helps to enhance the productivity of acidic soils, fighting erosion and runoff in SouthWestern regions. Economically, the government of Rwanda views the tea sector in the loop of increasing tea export volumes reaching $3 \%$ of the global market by 2024 (NAEB, 2019).

Please cite as: Kabayiza A., Owuor G., Langat K.J., Mugenzi P. and Niyitanga F. (2021). Does credit utilization lead to increasing farm outcome? A micro-perspective of tea production from Rwanda. Agro-Science, 20 (2), 92-100. DOI: https://dx.doi.org/10.4314/as.v20i2.15 
Government policies for tea sector improvement started back in 1999 with a reform program that aimed to privatize the governmentowned tea factories and plantations to stimulate investment in the sector while attracting foreign investment (Essama-Nssah et al., 2008). The privatization was accompanied by the introduction of a new green leaf pricing scheme to provide an incentive for tea growers in order to increase the quality of produced green tea leaf and production to meet the demand of installed tea factories in 2006 (MINAGRI, 2012). The tea expansion program of 2012-2017; which include planting new 18,000 ha of tea plantations (of which 10,000 ha of new sites and construction of five new factories in South-West regions of the country were executed), was meant to boost the quality and productivity of tea farms as well as providing access to inputs by farmers and enhanced capacity building for farmers including ensuring better R\&D efforts towards better high yielding clones of tea for farmers (NAEB, 2019). The above interventions have caused high demand for tea credit, and the utilization of this credit remains necessary for intensive production and sector growth (Abedullah et al., 2009; Bekun et al., 2018).

Though the production of tea factories in Rwanda is still challenged by the small-scale tea production system by independent farmers who own $70 \%$ of total tea plantations, the situation is coupled with the rate of effective utilization of agricultural credit obtained by farmers which remain suboptimal (World Bank, 2018). These observed critical cases are when farmers fully or partially divert credit from initial purpose to offfarm uses that affect the optimal production of green tea leaf and farmers' income (Bashiru et al., 2014; Vedamurthy et al., 2014; Reza et al., 2017).

Available studies have been attached to limited determinants of financing the sector and the barriers to reaching the optimum tea farm investment such as limiting factors to borrow from formal sources for the desired size to raise tea investment by small scale farmers (Musabanganji et al., 2015). Others analysed the farmers' participation in formal credit markets in rural areas of Rwanda (Muhongayire et $a l ., 2013$ ) and availability and affordable financial services in rural areas (Malimba and Ganesan, 2010; Fuglie et al., 2013). However, an analytical tool for decoupling credit utilization on the farm and nonfarm investment is missing to give a comprehensive credit effect on farm income. There is also a need for a study that accounts for self-selection to measure the effect of utilization of credit on tea income.

This study analysed the effect of credit utilization on tea income among tea farming households in Nyaruguru District, Rwanda. Additionally, the study assessed whether credit utilization is a viable strategy in increasing green tea leaf production in the area.

\section{MATERIALS AND METHODS \\ Data Collection}

The study used primary data collected through a farmers' survey. A stratified sampling technique to select tea farming households in Nyaruguru district. The district was chosen purposively because tea production is amongst the economic activities, employment and source of income in the area. The district has been also implementing the national tea expansion program since 2012 that aimed at increasing land size under tea and rate of inputs application to meet the national targets for the sector.

Two cooperatives were purposively selected; COTHENK and COOTHEMUKI both have 3,445 members. These tea cooperatives are operating along Nyungwe National Park from the South-West to the North-West in the district of Nyaruguru.

From a population of 3,445 tea farming households of the two cooperatives; COTHENK with 2,560 and COOTHEMUKI with 885 farmers respectively, a total of 358 farmers was calculated as the sample size for the survey interview of which 266 and 92 farmers were randomly selected from the two cooperatives, respectively. The following formula of Yamane (1967) was used to calculate the sample from the population and the stratum respectively:

$$
n=\frac{N}{1+N(e)^{2}} \quad \text { and, } n_{i}=\mathrm{n} \frac{N_{i}}{N}
$$

with $\boldsymbol{n}=$ estimated total sample size; $\boldsymbol{N}=$ total population size; $\boldsymbol{N}_{\boldsymbol{i}}=$ total population size in the stratum; $\boldsymbol{n}_{\boldsymbol{i}}=$ estimated sample size in the stratum; and $\boldsymbol{e}=$ represents the level of precision.

Tea farmers in each cooperative were further classified into two groups based on the records about credit utilization performance from their respective cooperatives. The performance is typically evaluated as the rate in percentage at which a received credit was utilized for exclusively tea production. i.e., reported credit diversion or non-diversion cases. The stratified technique was to ensure the representation of targeted respondents in the specific strata.

Data collection activity used three methods; questionnaires to collect quantitative data from tea farmers, cooperatives' records and reports and key informants for additional information. The survey was conducted face-to-face to interviewing heads of the households. Quantitative data included the gross margin income from tea farms in Rwandan currency where its equivalent US dollar could be estimated at 950Frw per 1USD in the period of the survey.

\section{Endogenous Switching Regression (ESR) Model Specification}

The credit utilization for the intended project for a farmer is driven by projected gross margin under assumptions. Modelling the situation assumes that the utility (tea farm outcomes) a farmer $i$ derives by allocating fully accessed credit for tea production or non-diverted credit is $y_{N D C}$ and the utility when diverting credit for out of tea production or diverted credit is symbolized as $y_{D C}$. 
The two groups of farmers can be expressed as:

$$
\begin{aligned}
& y_{i N D C}=x_{i} \beta_{N D C}+\varepsilon_{i N D C} \text { and, } \\
& y_{i D C}=x_{i} \beta_{D C}+\varepsilon_{i D C}
\end{aligned}
$$

where $x_{i}$ is a vector of explanatory variables; $\beta_{N D C}$ and $\beta_{D C}$ are parameter estimates for non-diverted and diverted credit categories, respectively; and $\varepsilon_{i N D C}$ and $\varepsilon_{i D C}$ are independent and identically distributed error terms. If a farmer expects to derive the higher gross margin by utilizing credit for tea production, this case is expressed as $y_{i N D C}>y_{i D C}$. To account for selection and switching between two regimes, the ESR model addresses the issue in two stages. The first is the selection model for utilizing received credit for tea production or alternative uses. That is $D_{i}^{*}$, a latent variable determines which regime the tea household farmer faces:

$D_{i}^{*}=\gamma_{i} z_{i}+u_{i} ; D_{i}=1$ if $D_{i}^{*}>0 ; D_{i}=0$ if $D_{i}^{*} \leq 0$

where $D_{i}$ is a binary variable that takes the value 1 for non-diverted credit regime and zero for diverted credit regime, and $\gamma_{i}$ is a vector of parameters to be estimated as the marginal effect of being in one of the two regimes. The error term is $u_{i}$ with mean as zero and variance $\sigma_{\varepsilon}^{2}$ for measuring errors. Variables $Z_{i}$ represent the independent instrument that includes unmeasured confounding factors and attributes that influence the decision of utilizing credit for tea enterprise or not.

The second stage is the tea farm outcome (i.e., quantity of green tea leaves produced) or farm income equation that split the endogenous model into two regimes (Maddala, 1983; Lokshin and Sajaia, 2004). Following the arguments in the equation 3 , description of the two regimes, farmers' category takes the following values:

$$
\begin{aligned}
& \text { Regime 1: Non-Diverted Credit (NDC): } \\
& y_{1 i}=\beta_{1} x_{1 i}+\varepsilon_{1 i} \quad \text { if } D_{i}=1 \\
& \text { Regime 2: Diverted Credit (DC): } \\
& y_{2 i}=\beta_{2} x_{2 i}+\varepsilon_{2 i} \quad \text { if } D_{i}=0
\end{aligned}
$$

where $y_{i N D C}$ and $y_{i D C}$ are gross margins from nondiverted and diverted credit farmer's regimes, respectively; $x_{1 i}$ and $x_{2 i}$ vectors of independent variables; $\beta_{1}, \beta_{2}$ and $\gamma$ are parameters to be estimated; $\varepsilon_{1 i}$ and $\varepsilon_{2 i}$ are error terms for nondiverted and diverted credit farmers, respectively; and $D_{i}$ is a dummy variable to distinguish the two regimes. It measures endogenous to farm income $y_{i}$ and to other exogenous variables $x_{i}$, which must be captured in the ESR model.

The self-selection caused by the correlation of the error terms of the decision and the gross margin equations. Maddala (1983) explained that error term $u_{i}$ is linked to the error terms $\left(\varepsilon_{1 i}, \varepsilon_{2 i}\right)$ in Eq.4. The three errors are correlated and have a positive value i.e., corr $\left(u_{i}, \varepsilon_{1 i}, \varepsilon_{2 i}\right) \neq 0$. In other words, the error terms $u_{i}, \varepsilon_{1 i}$ and $\varepsilon_{2 i}$ have a trivariate normal distribution, with mean vector zero and covariance matrix expressed as:

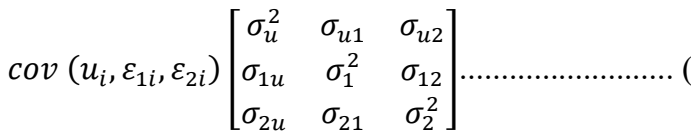

where the variance of the error terms in the selection equation and the two gross margin regimes 1 and 2 is denoted by $\sigma_{u}^{2}, \sigma_{1}^{2}$ and $\sigma_{2}^{2}$, respectively. This variance can be expressed mathematically as; $\sigma_{u}^{2}=$ $\operatorname{var}\left(u_{i}\right) ; \sigma_{1}^{2}=\operatorname{var}\left(\varepsilon_{1 i}\right)$ and $\sigma_{2}^{2}=\operatorname{var}\left(\varepsilon_{2 i}\right)$.

The covariance of the error terms from the selection equation $u_{i}$ and the gross margin regimes $1\left(\varepsilon_{1 i}\right)$ and $2\left(\varepsilon_{2 i}\right)$ is, respectively, denoted by $\sigma_{u 1}$ and $\sigma_{u 2}$. Mathematically, the respective covariance between error terms is expressed as; $\sigma_{u 1}=\operatorname{var}\left(u_{i}, \varepsilon_{1}\right)$ and $\sigma_{u 2}=\operatorname{var}\left(u_{i}, \varepsilon_{2}\right)$.

However, as two outcome equations for two regimes i.e., $y_{1 i}$ and $y_{2 i}$ variables can never be observed simultaneously for a single tea farmer, the $\sigma_{12}$ or $\sigma_{21}$ in the covariance matrix is therefore not present (Maddala, 1983).

From the aforementioned equation (4), the values of the error terms for the two regimes $\left(\varepsilon_{1 i} \mid D=1\right)$ and $\left(\varepsilon_{2 i} \mid D=0\right)$ are different from zero. They estimated using probit in the first stage of the endogenous switching regression model (ESR) to produce Inverse Mill Ratios (IMR); $\lambda_{1 i}$ and $\lambda_{2 i}$ estimates (Greene, 2002) as follows:

$$
\begin{gathered}
E\left(\varepsilon_{1 i} \mid D_{i}=1\right)=E\left(\varepsilon_{1 i} \mid u_{i}>-\gamma_{i} z_{i}\right) \\
=\sigma_{1 u}\left[\frac{\phi\left(\gamma_{i} z_{i}\right)}{\Phi\left(\gamma_{i} z_{i}\right)}\right] \equiv \sigma_{1 u} \lambda_{1 i} \\
\begin{aligned}
E\left(\varepsilon_{2 i} \mid D_{i}=0\right)=E & \left(\varepsilon_{2 i} \mid u_{i} \leq-\gamma_{i} z_{i}\right) \\
= & \sigma_{2 u}\left[\frac{-\phi\left(\gamma_{i} z_{i}\right)}{1-\Phi\left(\gamma_{i} z_{i}\right)}\right] \equiv \sigma_{2 u} \lambda_{2 i}
\end{aligned}
\end{gathered}
$$

where $\phi$ and $\Phi$ are the standard normal probability and cumulative distribution functions, respectively. The ratio of $\phi$ and $\Phi$ evaluated at $\gamma_{i} z_{i}$ (Eq. 6) is referred to as the Inverse Mills Ratio $\lambda_{1 i}$ and $\lambda_{2 i}$ (selectivity terms).

In the second stage of the ESR, the predicted variables in the Eq. 6 are then added to the appropriate equation in Eq. 4 to yield:

$$
\begin{aligned}
& y_{1 i}=\beta_{1} x_{1 i}+\sigma_{1 u} \lambda_{1 i}+u_{1 i} \quad \text { if } D_{i}=1 \text { and, } \\
& y_{2 i}=\beta_{2} x_{2 i}+\sigma_{2 u} \lambda_{2 i}+u_{2 i} \quad \text { if } D_{i}=0
\end{aligned}
$$

where $u_{1 i}$ and $u_{2 i}$ have zero conditional means. The coefficients of the variables $\lambda_{1 i}$ and $\lambda_{2 i}$ provide estimates of the covariance terms which are represented by $\sigma_{1 u}$ and $\sigma_{2 u}$, respectively. The difference of Inverse Mills Ratios between the two regimes is based on comparative advantage and would expect to be positive, i.e., $\sigma_{1 u}-\sigma_{2 u}>0$ to indicate that utilizing credit for tea production would result from higher yield and gross margin than investing out of tea enterprise. The movestay command in the STATA 16 is sufficient to run the endogenous switching regression model.

The signs and significance of correlation coefficients $\left(\sigma_{1 u}\right.$ and $\sigma_{2 u}$ ) of the error terms from estimated two regimes' equations (treatment and outcome equations. i.e., Eq. 7) have meaningful 
interpretation (Maddala, 1983; Awotide et al., 2015). If either $\sigma_{1 u}$ or $\sigma_{2 u}$ is significantly different from zero there is endogenous switching which would result from the selection bias. If $\sigma>0$ a negative selection bias is present. The interpretation of this would mean that tea farmers with below average gross margins are more likely to utilize credit for tea production. On other hand, if $\sigma<0$ a positive selection bias is present meaning that tea farmers with above average gross margins are more likely to utilize credit for tea production. Similarly, Fuglie and Rada (2013) argued that if both $\sigma_{1 u}$ or $\sigma_{2 u}$ coefficients have alternative signs, the credit utilisation choice is done based on comparative advantage; farmers who utilize credit for tea production earn above-average returns from utilization and those who diverted credit earn aboveaverage returns from alternative uses. On the other hand, if the coefficients have the same sign, farmers who utilise credit earn above-average returns whether they utilize credit for tea production or not, but they are better off by utilizing credit for tea.

\section{Estimating Treatment and Heterogeneity Effects on Tea Production and Gross Margin}

The estimation of the average treatment effect on the treated (ATT) and untreated (ATU) is estimated using the aforementioned endogenous regression model results by comparing two groups. The observed values of tea farm income for non-diverted credit and diverted credit farmers' groups are computed as follows:

$$
\begin{aligned}
& \text { Non-Diverted Credit (NDC) observed in the sample: } \\
& {\left[y_{1 i} \mid D=1\right]=\beta_{1} x_{1 i}+\sigma_{1 u} \lambda_{1 i}} \\
& \text { Diverted Credit (DC) observed in the sample: } \\
& {\left[y_{2 i} \mid D=0\right]=\beta_{2} x_{2 i}+\sigma_{2 u} \lambda_{2 i}}
\end{aligned}
$$

where $D=1$ for the non-diversion case and $D=0$ for the diversion case; $y_{1 i}$ and $y_{2 i}$ are tea farm income for non-diverted and diverted farmers' regimes, respectively. In the same style, the counterfactual expected tea farm income for two groups is:

$$
\begin{aligned}
& \text { Non-diverted credit counterfactual } \\
& {\left[y_{2 i} \mid D=1\right]=\beta_{2} x_{1 i}+\sigma_{2 u} \lambda_{1 i}} \\
& \text { Diverted credit counterfactual } \\
& {\left[y_{1 i} \mid D=0\right]=\beta_{1} x_{2 i}+\sigma_{1 u} \lambda_{2 i}}
\end{aligned}
$$

The average treated effect (ATT) of credit utilization on tea farm income for non-diverted credit group is computed as the difference between equations 8 and 10 as follows:

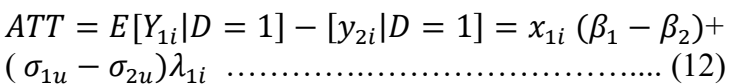

and the average treated effect (ATU) of credit utilization on tea farm outcomes for diverted credit group (untreated) is computed as the difference between equations (11) and (9) as follows:

$A T U=E\left[Y_{1 i} \mid D=0\right]-\left[y_{2 i} \mid D=0\right]=x_{2 i}\left(\beta_{1}-\beta_{2}\right)+$

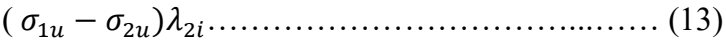

The base heterogeneity $(\mathrm{BH})$ effects refer to the differences in the tea farm outcomes due to the inherent differences besides tea production such as having other businesses and not that of the treatment can be computed. The heterogeneity effect for the non-diverted credit group is computed as the difference between equations (8) and (11);

$$
\begin{aligned}
& {\left[y_{1 i} \mid D=1\right]-\left[y_{1 i} \mid D=0\right]} \\
& =\beta_{1}\left(x_{1 i}-x_{2 i}\right)+\sigma_{1 u}\left(\lambda_{1 i}-\lambda_{2 i}\right)
\end{aligned}
$$

and that of the diverted credit group as the difference between equations (10) and (9);

$$
\begin{aligned}
& {\left[y_{2 i} \mid D=1\right]-\left[y_{2 i} \mid D=0\right]} \\
& =\beta_{2}\left(x_{1 i}-x_{2 i}\right)+\sigma_{2 u}\left(\lambda_{1 i}-\lambda_{2 i}\right)
\end{aligned}
$$

Finally, transitional heterogeneity (TH) is estimated as if the effect of utilising credit is larger or smaller for the farmers that utilized credit for tea production or for the farmers that diverted credit in the counterfactual case. That is the difference between equations (12) and (13); i.e., (ATT) and (ATU).

\section{RESULTS AND DISCUSSION Characteristics and Descriptive Statistics of the Respondents}

The age of the respondent is positive and significant at a 5\% level (Table1). This implies that farmer's age is positively correlated with credit utilisation decision. This also shows that older farmers show the uprightness in utilising credit for tea production than youth as they are risk-averse to venture for income diversification (Langyintuo and Mekuria, 2005).

In the results (Table1), the mean difference of size of tea plantation owned was found to be no significant between the two groups of household farmers. This is possible because tea plantation is a long-term cycle plant and its production can be improved by using input fertilisers and technical efficiency (Nguyen-Van and To-The, 2016). The mean difference of labour cost is significant at a $5 \%$ level indicating that credit users for tea production invest Frw 65,507 per hectare more than that of diverting credit. Similarly, input fertiliser with a significant mean difference (at 1\%) of Frw 52,495 per hectare indicating that credit users for tea production invest more than their counterpart non-users.

The size of credit accessed is also significant at a $1 \%$ level indicating that farmers who divert credit to off-farm investment have averagely accessed Frw 249,067 more amount than uprightness group that utilise credit for intended tea projects. The explanation is that having off-farm income can reduce the perception of risk for lending institutions especially when borrowers can show different repayment options (Awotide et al., 2015).

Income from tea production was found to have an aggregated mean of Frw 881,827 per hectare per quarter. However, farmers who divert credit to off- 
tea farm investment earn income (significant at 5\%) less than (Frw 416,045) that of utilising credit for tea production. The result is empirically argued that higher farm income improves technical efficiency and capacity to jumpstart agricultural innovation (Amsalu and De Graaff, 2007). Other farmers' characteristics are not significant for the two farmers' categories such as the level of education and gender of the household head, the size of household and experience in tea farming.

The females constitute a minority in both farmers' regimes (Table 2). Males represent $83.7 \%$ and $81.2 \%$ of non-diverted and diverted farmers' categories respectively while females represent $16.2 \%$ and $18.8 \%$ respectively. However, the chisquare test shows no association between the gender of the household head and credit utilisation decision.

The results show also that among farmers who accessed credit in groups, around $60.3 \%$ have utilised credit for tea production while $44.3 \%$ of them have diverted credit. The chi-square test is significant indicating that disbursement of credit in groups has a positive association with farmers' decision when utilising credit. The results also supported that borrowing in the group itself increases bargaining power for members upon presenting collective responsibility while reducing the perception of repayment risk (Shiferaw et al., 2014). Specifically, farmers who accessed the credit of input fertilisers that are channelized through farmers' cooperatives are likely utilizing them for intended projects because of close supervision of the group leaders compared to their counterparts who individually accessed the credit.
The result for borrowing status revealed that household farmers were not constrained at $80.7 \%$; which means that they had received desired credit amount. Out of them, $75.1 \%$ have utilised accessed credit for intended tea projects while $88.6 \%$ have diverted credit to off-farm uses. The chi-square test is positively significant indicating that there is an association between accessed amount and credit utilization decision of farmers.

The adoption of good agricultural practices (GAP) is significant indicating its influence on how farmers utilizing credit for tea production. Around $93.3 \%$ and $89.9 \%$ of non-diverted and diverted farmers' groups respectively have participated in organised training on good agricultural practices (GAP). Training on credit use and credit management offered by formal lending institutions to tea farmers was not significant to influence the decision of farmers for credit utilization. The results also show that there is a positive and significant association between running off-tea farm businesses and farmers' decision for credit utilisation. Statistically, only $28.7 \%$ of farmers that having offtea businesses have utilised credit to objectively intended tea projects while $71.5 \%$ have preferred to invest accessed credit out of tea enterprise. The positive association between credit diversion from intended project to off-farm businesses have been empirically highlighted in various contexts. Oboh and Ekpebu (2011) and Hussan (2013) argued that farmers divert credit to either diversify income or risk mitigation. As management, training on loan management and regular visit of bank supervisors to credit beneficiaries were highly recommended for some cases in Nigeria and Pakistan.

Table 1: Tea household farmers' characteristics for continuous variables ( $t$-statistic)

\begin{tabular}{|c|c|c|c|c|}
\hline \multirow{3}{*}{ Continuous variables } & \multicolumn{3}{|c|}{ Mean difference of tea household characteristics by farmer's regime } & \multirow{3}{*}{$t$-Statistic } \\
\hline & $\mathrm{NDC}(n=209)$ & $\mathrm{DC}(n=149)$ & Mean difference & \\
\hline & Mean & Mean & & \\
\hline Age of HH (years) & $53.23(0.84)$ & 50.52 & 2.71 & $-2.1440^{* *}$ \\
\hline Education of $\mathrm{HH}$ (years) & $5.23(0.30)$ & $5.32(0.35)$ & $0.09(0.46)$ & 0.1869 \\
\hline Size of HH (no. of dependents) & $6(0.14)$ & $6(0.15)$ & $0.20(0.20)$ & 0.9566 \\
\hline Experience of $\mathrm{HH}$ in tea farming (years) & 7.23 & 7.40 & 0.17 & 0.7164 \\
\hline Size of tea plantation $(\mathrm{Ha})$ & $0.99(0.06)$ & $0.89(0.07)$ & $0.10(0.09)$ & -1.1422 \\
\hline Tea labour cost (Frw/ha/quarter) & $177,978.4(21,490.76)$ & $112,470.7(16,839.21)$ & $65,507(29,159.6)$ & $-2.2465^{* *}$ \\
\hline Tea input cost (Frw/ha/quarter) & $140,162.8(13,770.72)$ & $87,668.08(9,958.21)$ & $52,494.69(18,352.84)$ & $-2.8603^{* * *}$ \\
\hline Size of credit accessed (Frw) & $370,411(37,546)$ & $619,478(68,009)$ & $-249,067(72,613)$ & $3.4300^{* * *}$ \\
\hline Tea farm income (Frw/ha/quarter) & $881,827(131,772)$ & $465,782(83,791)$ & $416,045(171,392)$ & $2.4274^{* *}$ \\
\hline
\end{tabular}

${ }^{* * *} 1 \%$ level of significance; ${ }^{* *} 5 \%$ level of significance; ${ }^{*} 10 \%$ level of significance

Table 2: Tea household farmers' characteristics for discrete dummy variables $\left(C h i^{2} t e s t\right)$

\begin{tabular}{|c|c|c|c|c|}
\hline Dummy variables & Sample & $\begin{array}{c}\mathrm{NDC}(n=209) \\
\%\end{array}$ & $\begin{array}{c}\mathrm{DC}(n=149) \\
\%\end{array}$ & $\chi^{2}$ \\
\hline Gender $($ Male $=1)$ & 82.68 & 83.73 & 81.21 & \multirow{2}{*}{0.3870} \\
\hline$($ Female $=0)$ & 17.32 & 16.27 & 18.79 & \\
\hline Credit groups $($ Yes $=1)$ & 53.63 & 60.29 & 44.30 & $8.9454^{* * *}$ \\
\hline Credit non-constrained $($ Yes $=1)$ & 80.73 & 75.12 & 88.59 & $10.1454^{* * *}$ \\
\hline Training on tea GAP $($ Yes $=1)$ & 87.71 & 93.30 & 79.87 & $14.5664^{* * *}$ \\
\hline Training on credit management $($ Yes $=1)$ & 24.02 & 26.79 & 20.8 & 2.1140 \\
\hline Off-tea farm income activities (Yes $=1$ ) & 45.81 & 28.71 & 71.50 & $59.1634^{* * *}$ \\
\hline
\end{tabular}

${ }^{* * *} 1 \%$ level of significance, ${ }^{* *} 5 \%$ level of significance; ${ }^{*} 10 \%$ level of significance 


\begin{abstract}
Determinants of Credit Utilization on the Tea Farm Income and Factors Influencing Gross Margins The results of endogenous switching regression using full information maximum likelihood are presented in Table 3. The first column presents the estimated coefficients of the selection equation on utilization of credit for tea production or diverted to out of tea farm uses. The next two columns (second and third) present the estimated coefficients of the outcome equations of tea farm income for the two regimes of farmers as non-diverted and diverted groups or simply credit users and credit non-users of credit for tea projects, respectively.
\end{abstract}

\section{Factors Influencing Tea Farm Income}

Turning to the Endogenous Switching Regression (ESR) estimates, the selected variables used in the estimation are farm, institutional and household characteristics that are associated with credit utilization. The dependent variable is the logarithm of income from owned tea plantations calculated as the price per kilogram paid by a factor multiplied by the total quantity (in $\mathrm{kg}$ ) of supplied green tea leaves.

The Wald $\chi^{2}$-test statistic is highly significant indicating the goodness of fit of our ESR model $(p$-value $=0.000)$. The likelihood ratio test (14.35) of independence of selection and tea farm outcome equations is significant at $1 \%(p<0.000)$ suggesting that the ESR model variables are jointly validated as strong predictors for credit utilisation. An interesting finding is the signs and significance of the covariance terms $\left(\rho_{U}\right.$ and $\left.\rho_{N U}\right)$. The correlation coefficient $\boldsymbol{\rho}_{U \varepsilon}$ indicates the correlation between credit utilization situation and its effect on tea farm outcomes by tea credit users. While the correlation coefficient $\boldsymbol{\rho}_{N U \varepsilon}$ indicates the correlation between credit utilization situation and its effect on tea farm outcomes by tea credit non-users.

The results show that the covariance terms for both regimes are all significant, indicating that the self-selection occurred in credit utilization decision. Thus, utilizing credit for tea production may not have the same effect on those who divert credit, if they choose to utilise it for tea projects as well. Moreover, having the same signs, positive and statistically significant for both farmers' categories implies that utilizing credit has a significant positive effect on farm outcomes (yields and net returns), thus credit user farmers obtained higher yields and net returns than a random individual from the sample would obtain. This is also confirmed since the necessary conditions for consistency are fulfilled $\left(\rho_{U}>\rho_{N U}\right)$ indicating that credit users for tea production obtain a higher outcome than they would if they deviate credit to off tea uses.

The ESR estimates show that the positive and significant variables of gross margins of tea credit users are; age, size of tea plantation, experience in tea farming, training on good agricultural practices, visits of lending institutions officers for monitoring, the cost of hired labour and input fertilisers. For tea credit non-users we have; the size of tea plantation, experience in tea farming, training on good agricultural practices, training on credit use and management, cost of hired labour and input fertilisers as well.

Age has a positive impact on tea farm income for tea credit users. Association of age with tea income implies that older people may be more riskaverse and reluctant to start off-farm ventures than younger people who are risk-takers. Therefore, there is a low rate of tea credit diversion to off-tea production projects for elder people. The finding is in line with the findings of Adego (2019).

The investment for tea production is used as a proxy of credit utilization by obtaining inputs, hiring labour and all related inputs to produce green tea leaf. The results show that the size of the owned tea plantation is significantly associated with tea farm income for both farmers' regimes citeris paribus. A $1 \%$ increase in credit to purchase one hectare for tea development leads to an increase in farm income on credit user and credit non-user farmers at $45.4 \%$ and $32.8 \%$ respectively other factors held constant. This means that the volume of fresh tea leaves produced may be primarily dependent on the size of the tea plantations owned by a farmer. The results are in line with other findings that farm size is simultaneously an input factor and determinant of technical efficiency (Alvarez and Arias, 2003). Similarly, Kanburi Bidzakin et al. (2019) showed this association between the size of arable land and farm productivity.

The number of years in tea farming is linearly correlated with tea income for credit users and nonusers at 5 and $10 \%$ levels, respectively. This suggests that farmers' experience is related to the technical efficiency of tea production that results from using credit accessed to procure farm inputs and labour for tea maintenance activities. The results are supported by Maniriho and Bizoza (2018) who showed that tea is a long-term cycle plant and its production can be improved by using input fertilisers and cumulative technical efficiency especially know how to harvest qualitative green leaves during plucking.

Training sessions on good agricultural practices for tea production is a positive and significant determinant for tea income for both farmers' regimes. The results are plausible because technical efficiency is interconnected with the level of gained knowledge and skills by a farmer. Therefore, it is not surprising that tea production is likely increased when farmers apply skills and knowledge acquired from attended training as supported by Muzari et al. (2012). However, training on credit management does not influence gross margins for credit users. The finding shows that financial literacy is positive and significant for tea credit non-users farmers' regime. This is probably because borrowing from formal sources requires one to have a certain level of knowledge on credit management specifically to minimize credit defaulting cases. 
Table 3: Endogenous switching regression results for credit utilization and tea farm output equations (in ln of income)

\begin{tabular}{|c|c|c|c|}
\hline \multirow{2}{*}{ Variables } & \multirow{2}{*}{ Selection } & \multicolumn{2}{|c|}{ Gross margins } \\
\hline & & Credit users & Credit non-users \\
\hline Constant & $7.374(1.110)$ & $10.223(0.574)$ & $9.485(0.625)$ \\
\hline Gender & $-0.045(0.208)$ & $-0.024(0.204)$ & $0.113(0.221)$ \\
\hline Age & $0.009(0.007)$ & $0.013^{*}(0.008)$ & $0.009(0.007)$ \\
\hline Education & $0.018(0.020)$ & $-0.028(0.020)$ & $0.013(0.020)$ \\
\hline Tea plantation size & $0.112(0.103)$ & $0.454^{* * *}(0.106)$ & $0.328^{* * *}(0.109)$ \\
\hline Experience in tea farming & $-0.040(0.040)$ & $0.084^{* *}(0.038)$ & $0.071^{*}(0.040)$ \\
\hline Credit non-constrained & $-0.240(0.221)$ & $-0.265(0.263)$ & $0.150(0.196)$ \\
\hline Training on GAP ${ }^{1}$ & $0.965^{* * *}(0.254)$ & $0.483^{* *}(0.220)$ & $0.822^{* *}(0.350)$ \\
\hline Training on credit mgt & $0.758^{* * *}(0.221)$ & $0.327(0.221)$ & $0.466^{* *}(0.198)$ \\
\hline Lending fin. visits & $-0.145(0.175)$ & $0.384^{* *}(0.176)$ & $0.064(0.170)$ \\
\hline Tea labour cost & $0.340^{* * *}(0.068)$ & $0.127^{*}(0.070)$ & $0.170^{* * *}(0.051)$ \\
\hline Tea input cost & $0.317^{* * *}(0.091)$ & $0.245^{* * *}(0.090)$ & $0.180^{* * *}(0.059)$ \\
\hline Credit size & $-0.711^{* * *}(0.096)$ & & \\
\hline Off-tea farm businesses & $-0.892^{* * *}(0.167)$ & & \\
\hline Credit groups & $0.500^{* * *}(0.157)$ & & \\
\hline $\ln \sigma_{U}$ & & $-0.012(0.066)$ & \\
\hline$\rho_{U \varepsilon}$ & & $0.545^{* * *}(0.176)$ & \\
\hline $\ln \sigma_{\mathrm{NU}}$ & & & $0.157(0.057)$ \\
\hline$\rho_{\mathrm{NU \varepsilon}}$ & & & $0.467^{* *}(0.194)$ \\
\hline Log-likelihood & & -684.21 & \\
\hline Wald test (11) Prob > chi & & 117.10 & \\
\hline LR test of Indep. Eqns. $\chi^{2}$ & b. $>$ chi $2=0.0008$ & $14.35^{* * *}$ & \\
\hline
\end{tabular}

The findings also show that visits of officers from formal lending institutions are positively significant for effective credit utilization in particular for credit users. This is probably because this category of farmers spends a maximum of their time on tea farm activities and mostly live near tea production areas. The finding is supported by Uboh and Ekpebu (2011) who found that that the farmers visited by bank officials tend to assign more funds to the farm to mean that the absence of such regular visits tends to tempt farmers to divert credit to unintended uses.

The cost of hired labour is positive and linearly correlated with the farm yield in both categories. A $1 \%$ increase in credit to pay for supplementary manday leads to $17 \%$ increasing income for the group of farmers that usually diverted credit to off-farm uses. The higher significant labour cost for this group implies the cost of delegating farm managers by landlords as these are busy for other businesses comparing to their counterparts whose tea production is a daily and primary occupation. Therefore, close management of hired labour for tea plucking determine the amount of credit to allocate for labour which is the case for tea credit users whose daily and primary occupation are tea farm production activities. However, the cost of input fertilisers is positive and significant ( $1 \%$ level) for both farmers' regimes because they are procured and supplied in bulk through the cooperatives if farmers have to benefit from the subsidiary program for fertilizers by the central government. Similar to other findings, it was also expected that the rate of farm input fertilisers application increases with tea plantation size which is also significant to influence tea income thus increase the size of tea plantations require additional capital for purchasing inputs (Emerole et al., 2008; Uboh and Ekpebu, 2011).

\section{Factors of Tea Credit Utilization}

The ESR estimates show that the positive and significant variables of credit utilization for tea production are; good agricultural practices, training on credit use and management, cost of labour and input fertilisers and access to joint/group credit. The significant and negative factors are; the size of accessed credit and possession of off-farm businesses.

The results confirm that farmers' participation in various training increases their commitment and determines the farmer's ability to allocate accessed credit (Caswell et al.,2001). Like explained above, labour for tea maintenance and plucking activities demand more capital for a farmer thus a higher probability of using accessed credit for tea production. The cost of input fertilisers also plays an important role to influence the farmers' decision for credit allocation. Farmers with the higher cost of tea production are more likely to utilize accessed credit in purchasing related farm inputs.

Access to credit through farmers' cooperatives is positively significant at the $1 \%$ level for both farmers' regimes. This is possible because farmers are recommended to procure subsidized fertilisers in bulk through their organizations through the government subsidy program for fertilisers. This supply chain approach is monitored by cooperative leaders who have the voice in determining the farmer' eligibility for the credit scheme based on his/her farm size and past performance on utilisation. In most cases, the received fertilisers are later paid by deducting the amount on supplied green tea leaves at the level of tea factories and farmers receive the balance.

Factors like size of credit amount and off-farm businesses are significant and negatively affecting the farmer's decision of utilizing credit for tea

${ }^{1}$ Look for "diversion conclusion on Summary-desktop" Pakistan case 
production projects and the level of tea farm income. Possession of off-farm businesses is here referred to as a proxy of all possible sources of income out of tea enterprise. These include trading businesses or salaried jobs, etc. Our expected negative effect of offfarm businesses on credit utilization for intended projects is a result of endogeneity between agricultural production and off-farm businesses investment as income diversification strategy indicated by Musafiri and Sjölander (2018). Farmers can also present tea plantations as a collateral asset to access credit from formal lending sources mostly commercial banks and microfinance and later use it out of tea enterprise. Other factors are not significant and inconclusive to affect the decision of farmers to credit utilization.

\section{Estimates of the Impact of Credit from ESR Results}

As shown in Table 4, the impact of credit utilization for tea production is determined by differentiating the column of users and that of non-users. Cells (a) and (b) represent the expected tea income observed in the sample. The results reveal that the utilization of credit increases income for credit users compared with non-users. The expected mean income per hectare per quarter for a tea household farmer that utilised credit for tea production is about 969,155 Rwandan francs, while it is about 563,714 Rwandan francs for those who diverted credit. Therefore, those who objectively invest in tea production earn about 405,441 Rwandan francs (72\%) more than those who divert credit. The last column of Table 4 represents the treatment effect. For the counterfactual (c) case, tea household farmers who utilise credit gain 62,930 Rwandan francs (that is about 7\%) more than if they diverted credit. While for counterfactual (d) case, tea household farmers that diverted credit would have realised about 312,411 Rwandan Francs (that is about 55\%) more than if they utilise credit for intended projects for tea production.

The credit has a significant and positive impact on farm outcomes if farmers effectively use it for tea production purpose. The estimates show that those who diverted credit would averagely increase the gross margins by $55 \%$. These results are particularly important to design effective credit utilization strategies to cope with the potential impacts of tea production change. The findings are consistent with the literature showing that credit has a positive and significant impact on farm yields and income (Riaz et al., 2012; Awotide et al., 2015; Ponguane, 2016; Iddrisu et al., 2017).

Table 4: Impact of credit utilization on the tea farm income

\begin{tabular}{llll}
\hline \multirow{2}{*}{ Utilization status } & \multicolumn{2}{c}{ Utilization decision } & $\begin{array}{c}\text { Utilization } \\
\text { effect }\end{array}$ \\
\cline { 2 - 3 } & Utilized & Diverted & \\
\hline $\begin{array}{l}\text { Tea HH farmers } \\
\text { who utilized credit }\end{array}$ & (a) 969,155 & (c) 906,224 & ATT $=62,930$ \\
$\begin{array}{l}\text { Tea HH farmers } \\
\text { who diverted credit }\end{array}$ & (d) 876,125 & (b) 563,714 & ATU $=312,410^{* * *}$ \\
Heterogeneity effect & 93,030 & 342,510 & TH $=-249,480$ \\
\hline
\end{tabular}

\section{CONCLUSION}

The specific objective of the study was to analyse the effect of credit utilization on tea farm income and to assess whether credit utilization is a viable strategy in increasing green tea leaf production in the study area. The study employed purposive and random techniques to collect data through an interview survey for tea farming households.

The results revealed that credit employment has a positive effect on tea production and income. Tea farming households who utilized credits for intended tea production had earned at $7 \%$ more than if they diverted credit. While their counterparts who diverted credit could earn around 55\% if they choose to utilise credits for tea production purpose. Factors that are influencing the effective utilization of tea credits in the area include age, size of owned tea plantation, experience in tea farming, training on good tea agricultural practices and credit management, visits of bank officials, rate of input fertiliser application, labour and if credits are channelised through farmers' groups as well. Also, credits in cash and possession of off-farm businesses increased the rate of credits embezzlement and the level of tea farm income.

There is a need to make sure that all agricultural credit be utilized for the same purpose for which it was obtained. Policies and programs would enhance the provision of agricultural credit in kind mainly as physical inputs and be channelized through farmers' cooperatives to discourage credit diversion.

\section{ACKNOWLEDGEMENT}

This paper is a part of the work that was carried out with the support of the African Economic Research Consortium (AERC) for a $\mathrm{PhD}$ program in Agribusiness Management, Egerton University, Kenya. The support is acknowledged.

Notes: 1. Tea gross margin was estimated as the amount in Rwandan Francs (exchange rate stood at US\$ $1.00=$ FRW 950.00 July 2019) paid for supplied tea-green leaves by a farmer per hectare per quarter; and $\mathbf{2}$. Interested readers can consult the Access to Finance, Rwanda and Agroinput subsidy program by the government of Rwanda.

\section{REFERENCES}

Abedullah N., Khalid M. and Kouser S. (2009). The role of agricultural credit in the growth of livestock sector: A case study of Faisalabad. Pakistan Vet. J., 29 (2), 81-84

Adego T., Simane B. and Woldie G.A. (2019). The impact of adaptation practices on crop productivity in northwest Ethiopia: an endogenous switching estimation. Dev. Studies Res., 6 (1), 129-141

Alvarez N. L. and Naughton-Treves L. (2003). Linking national agrarian policy to deforestation in the Peruvian Amazon: a case study of Tambopata, 19861997. AMBIO: A J. Human Environ., 32(4), 269-274

Amsalu A. and De Graaff J. (2007). Determinants of adoption and continued use of stone terraces for soil and water conservation in an Ethiopian highland watershed. Ecol. Econs., 61 (2-3), 294-302

Awotide B.A., Abdoulaye T., Alene A. and Manyong V.M. (2015). Impact of access to credit on agricultural productivity: Evidence from smallholder cassava farmers in Nigeria. Conf. of Int. Assoc. Agric. Economists, Milan, Italy, 9-14 Aug. 2015, No. 210969, https://EconPapers.repec.org/RePEc:ags:iaae15:210969 
Bashiru M., Dumayiri M. and Sabutey G.T. (2014). Analysis of the sources of farm investment credit in the Upper West Region of Ghana. Int. J. Current Res. Acad. Rev., 2 (5), 1-15

Bekun F.V., Hassan A. and Osundina O.A. (2018). The role of agricultural credit in agricultural sustainability: dynamic causality. Int. J. Agric. Resources Governance Ecol., 14 (4), 400-417

Di Falco S., Veronesi M. and Yesuf M. (2011). Does adaptation to climate change provide food security? A micro-perspective from Ethiopia. American J. Agric. Econs, 93 (3), 829-846

Emerole C., Nwosu A., Onyenweaku C., Ukoha O. and Nwachukwu A. (2008). Determinants of consumption expenditure and its share to total income in small farm households in Ikwuano, Abia State Nigeria. Global Approaches to Extension Practice: A Journal of Agricultural Extension, 3 (1), 1-11

Essama-Nssah B. and Ezemenari Kene and Korman V. (2008). Reading Tea Leaves on the Potential Impact of the Privatization of Tea Estates in Rwanda. World Bank Policy Research Working Paper No. 4566, Available at SSRN: https://ssrn.com/abstract=1111902

FAO (2020). FAOSTAT statistical database. Rome, Italy: Food and Agriculture Organization (FAO) of the United Nations. Retrieved $30^{\text {th }}$ Jan., 2020

Feder G., Lau L.J., Lin J.Y. and Luo X. (1990). The relationship between credit and productivity in Chinese agriculture: A microeconomic model of disequilibrium. American J. Agric. Econs, 72 (5), 1151-1157

Freeman H.A., Ehui S.K. and Jabbar M.A. (1998). Credit constraints and smallholder dairy production in the East African highlands: Application of a switching regression model. Agric. Econs., 19, 33-44

Fuglie K. and Rada N. (2013). Resources, policies, and agricultural productivity in sub-Saharan Africa. USDA-ERS Economic Research Report (145)

Government of Rwanda. 2012. Rwanda: Financial Sector Development Program II (2013-2017). Kigali, Rwanda

Greene W.H. (2002). Econometric Analysis (5th Ed.). New York: Prentice-Hall

Heckman J.J. (1979). Sample selection bias as a specification error. Econometrica, 47 (1), 153-161

Hussan T. (2013). Factors Influencing Demand for Credit from Formal and Informal Sources in Gujranwala District, Pakistan - a Case of Commercial Banks and Arties. A Masters' Thesis, Norwegian University of Life Sciences

Iddrisu A., Ansah I.G.K. and Nkegbe P.K. (2018). Effect of input credit on smallholder farmers' output and income: Evidence from Northern Ghana. Agric. Finance Rev., 78 (1), 98-115

Kanburi Bidzakin J., Fialor S.C., Awunyo-Vitor D. and Yahaya I. (2019). Impact of contract farming on rice farm performance: Endogenous switching regression. Cogent Econs. Finance, 7 (1), 1618229

Langyintuo A.S. and Mekuria M. (2005). Accounting for neighborhood influence in estimating factors determining the adoption of improved agricultural technologies. Annual Meeting, American Agric. Econs. Assoc., 24-27 Jul., 2005, Providence, RI 19521

Lee L.F. (1982). Some approaches to the correction of selectivity bias. Rev. Econ. Studies, 49 (3), 355-72

Lokshin M. and Sajaia Z. (2004). Maximum likelihood estimation of endogenous switching regression models. The Stata Journal, 4 (3), 282-289
Maddala G.S. (1983). Methods of estimation for models of markets with bounded price variation. Int. Econ. Rev., 42 (2), 361-378

Malimba M. and Ganesan P. (2010). Financial services consumption constraints: Empirical evidence from Rwandan rural households. J. Financial Services Marketing, 15 (2), 136-159

Maniriho A. and Bizoza A. (2013). Financial benefit-cost analysis of agricultural production in Musanze District (Rwanda). Acad. Arena, 5 (12), 30-39

Miguel E. and Michael K. (2004). Worms: Identifying impacts on education and health in the presence of treatment externalities. Econometrica, 72 (1), 159-217

MINAGRI (2012). Cabinet Briefing Paper: New tea green leaf pricing model to tea farmers in Rwanda. Kigali, Rwanda

Muhongayire W., Hitayezu P., Mbatia O.L. and MukoyaWangia S.M. (2013). Determinants of farmers' participation in formal credit markets in rural Rwanda. J. Agric. Sci., 4 (2), 87-94

Musabanganji E., Antoine K. and Lebailly P. (2015). Determinants of access to agricultural credits for small-scale farmers in the Southern Province of Rwanda. Sixth Int. Sci. Agric. Symp. "AgroSym 2015", Jahorina, Bosnia and Herzegovina, October 15-18, 2015. Book of Proceedings, 1815-1820

Musafiri I. and Sjölander P. (2018). The importance of off-farm employment for smallholder farmers in Rwanda. J. Econ. Studies, 45 (1), 14-26

Muzari W., Gatsi W. and Muvhunzi S. (2012). The impacts of technology adoption on smallholder agricultural productivity in sub-Saharan Africa: A review. J. Sustainable Dev., $5(\mathbf{8}), 69$

NAEB (2019). NAEB Strategic Plan 2019-2024: Increasing Agri-Export Revenues. Kigali, Rwanda

Nguyen-Van P. (2016). Technical efficiency and agricultural policy: evidence from the tea production in Vietnam. Rev. Agric., Food Environ. Studies, 97 (3), 173-184

Oboh V.U. and Ekpebu I.D. (2011). Determinants of formal agricultural credit allocation to the farm sector by arable crop farmers in Benue State, Nigeria. Afr. J. Agric. Res., 6 (1), 181-185

Ponguane S.J.A. (2016). Effects of Credit Subsidy on Smallholders Maize Productivity and Farm Income in Chókwè District, Mozambique. A Master's Thesis, Egerton University, Kenya

Reza S.N.S.M., Fathollah T. and Karim A. (2017). Affecting factors on credit diversion in Iran. J. Econ. Res. Policies, 25 (81), 187-228

Riaz A., Khan G.A. and Ahmad M. (2012). Utilization of agriculture credit by the farming community of ZARAI TARIQIATI BANK Limited (ZTBL) for agriculture development. Pakistan J. Agric. Sci., 49 (4), 557-560

Shiferaw B., Kassie M., Jaleta M. and Yirga C. (2014). Adoption of improved wheat varieties and impacts on household food security in Ethiopia. Food Policy, 44, 272-284

Vedamurthy K.B., Dhaka D.P. and Smita (2014). Dairy credit utilisation and repayment in Shimoga milk zone of Karnataka: A comparative analysis of SHGs, Commercial Banks and RRBs. Indian J. Dairy Sci., 67 (4), 339-344

World Bank (2013). Impact evaluation of tea sector reforms in Rwanda baseline household survey (Issue October)

World Bank (2018). Agriculture Finance Diagnostic Rwanda, 1-60 